\title{
Influence of Mechanical Alloying Parameters on Phase Formation in Al-Cu-Fe Powder
}

\author{
M. Mitka*, L. Lityńska-Dobrzyńska, A. Góral, W. Maziarz \\ Institute of Metallurgy and Materials Science, Polish Academy of Sciences, \\ W.S. Reymonta 25, 30-059 Kraków, Poland
}

\begin{abstract}
In the present study the effect of mechanical alloying parameters on phase formation in $\mathrm{Al}_{62} \mathrm{Cu}_{25.5} \mathrm{Fe}_{12.5}$ (at.\%) alloy was investigated. Mixtures of $\mathrm{Al}, \mathrm{Cu}$ and Fe powder with different particles size were ball milled in Fritsch 5 Pulverisette planetary mill using tungsten carbide vials and balls. The milling was performed with the rotation speed 250 and $300 \mathrm{rpm}$ up to $40 \mathrm{~h}$. Stearic acid or hexane were used as process control agent (PCA). The microstructure of the powders prepared with different milling parameters was investigated using X-ray diffraction and scanning electron microscopy. It was found that increase of the rotation speed as well as decrease of particle size of initial Al powder particles accelerates the formation of homogeneous microstructure of the powder. The mixture of icosahedral quasicrystal and $\beta-\mathrm{Al}(\mathrm{Cu}, \mathrm{Fe})$ cubic phase has been obtained for the powders milled at $300 \mathrm{rpm}$ up to $20 \mathrm{~h}$. Prolonged milling time results in transformation to single ordered $\beta$ phase.
\end{abstract}

DOI: 10.12693/APhysPolA.126.984

PACS: 81.05.Bx, 81.20.Ev, 61.44.Br, 61.05.cp, 68.37.Hk

\section{Introduction}

Quasicrystals, aperiodic long-range ordered structures were found in many alloys, especially in binary and ternary aluminium systems containing transition metals. The unique properties, such as high hardness, low surface energy, good wear resistance, low friction coefficient and low thermal and electrical conductivity make the quasicrystals suitable for application as coating or reinforcement in metal matrix composites [1]. Stable quasicrystals in $\mathrm{Al}-\mathrm{Cu}-\mathrm{Fe}$ ternary system are intensively studied last years because of the low cost, easily accessible and nontoxic components [2]. Preparation of single-phase Al-CuFe quasicrystal by conventional casting is difficult due to its narrow compositional range, whereby the rapid solidification (RS) or mechanical alloying (MA) techniques are applied [3-20]. As for the MA method, the materials are obtained in the form of fine powder suitable for the applications. Many examples of synthesis of the Al-Cu-Fe quasicrystalline phase by MA with and without subsequent annealing treatments have been reported [7-20]. The mechanism of quasicrystal formation is determined by the milling parameters, including material of the milling media, the process control agents and milling atmosphere used, time and energy of milling process. For example, the quasicrystalline phase was obtained directly in $\mathrm{Al}_{65} \mathrm{Cu}_{20} \mathrm{Fe}_{15}$ alloy by milling for $15 \mathrm{~h}$ [7] or by ultra high energy milling for short time up to $1 \mathrm{~h}[8,9]$, contrary to results obtained by Eckert et al. [10], where the quasicrystalline phase was not observed even after milling up to $374 \mathrm{~h}$. It was found also that the quasicrystalline phase is unstable with long milling time and transforms

* corresponding author; e-mail: m.mitka@imim.pl to cubic $\beta-\mathrm{Al}(\mathrm{Cu}, \mathrm{Fe})$ phase $[11-13]$. The subsequent heat treatment of the as-milled powder in the temperature range $600-800^{\circ} \mathrm{C}$ can lead to the transformation to quasicrystalline phase, however ball milling parameters have a significant influence on the final phase composition of annealed powder [14-20].

In the present study the influence of milling speed, milling time, particle size of initial powder and process control agent (PCA) to obtain quasicrystals in $\mathrm{Al}_{62} \mathrm{Cu}_{25,5} \mathrm{Fe}_{12,5}$ (at.\%) alloy by mechanical alloying was investigated.

\section{Experimental}

Elemental powders of aluminum, copper, and iron of purity $99.9 \%$ were mechanically alloyed to prepare the $\mathrm{Al}_{62} \mathrm{Cu}_{25.5} \mathrm{Fe}_{12.5}$ (at.\%) alloy. The average size of both $\mathrm{Cu}$ and $\mathrm{Fe}$ powder particles was $10 \mu \mathrm{m}$. In the case of Al two different powder particles were used: first of average size of $10 \mu \mathrm{m}$ and the second of the size in the range $44-88 \mu \mathrm{m}$. Mechanical alloying was carried out in argon atmosphere using Fritsch Pulverisette P-5 planetary mill with rotation speed of 250 or $300 \mathrm{rpm}$ (rotation per minute). Milling was performed using tungsten carbide (WC) vials and balls (10 $\mathrm{mm}$ diameter) to avoid $\mathrm{Fe}$ contamination from steel milling media. The powders were milled at a ball to powder weight ratio of 10:1. To investigate influence of PCA on milling different substance were applied: stearic acid (1 wt\%) or hexane. Approximated values of energy transferred to the powder particles during milling were calculated for the used process conditions on the basis of the formula presented in $[21,22]$. The total energy moved was $4.57 \mathrm{MJ} / \mathrm{kg} / \mathrm{h}$ and $7.9 \mathrm{MJ} / \mathrm{kg} / \mathrm{h}$ for $250 \mathrm{rpm}$ and $300 \mathrm{rpm}$, respectively. These energies were about twice higher if compared to the milling by using steel ball and vials with the same milling parameters. 
For the phase analysis of as-milled powders after different milling time XRD measurements were done using D2 Phaser Bruker diffractometer with $\mathrm{Cu} K_{\alpha}$ filtered radiation. Selected powders were embedded in epoxy resin, grinded, polished and investigated by scanning electron microscope E-SEM XL30.

\section{Results}

Figure 1 shows the X-ray diffraction patterns for mechanically alloyed $\mathrm{Al}_{62} \mathrm{Cu}_{25.5} \mathrm{Fe}_{12.5}$ powder after different milling time prepared by using large initial $\mathrm{Al}$ powder of the size $44-88 \mu \mathrm{m}$ and the stearic acid as PCA. The rotation speed of the mill was $250 \mathrm{rpm}$. Up to $20 \mathrm{~h}$ of milling the reflections of elemental $\mathrm{Al}, \mathrm{Cu}$ and $\mathrm{Fe}$ phases were clearly visible, similarly as in the mixture of starting powders. After $40 \mathrm{~h}$ of milling the peaks of $\mathrm{Al}, \mathrm{Cu}$ and $\mathrm{Fe}$ phases disappeared completely and new broad maximum occurs at about $44^{\circ}$ of $2 \Theta$ angle. This reflection and the weak peak at $64^{\circ}$ position could be identified as $\beta-\mathrm{Al}(\mathrm{Cu}$, $\mathrm{Fe})$ cubic phase. The $\beta$ phase was identified in $\mathrm{Al}-\mathrm{Cu}-\mathrm{Fe}$ milled powder by many researchers $[14,15,19]$.

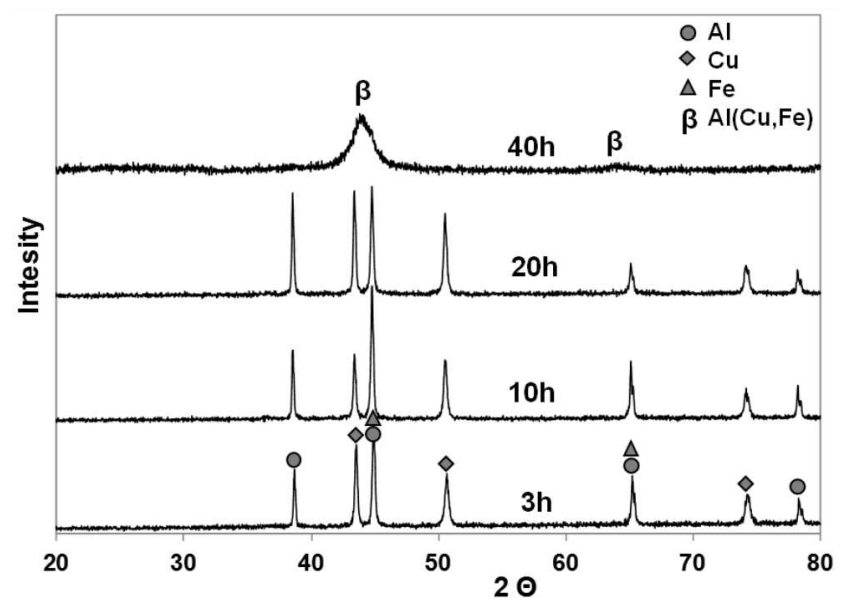

Fig. 1. X-ray diffraction patterns of mechanically alloyed $\mathrm{Al}_{62} \mathrm{Cu}_{25.5} \mathrm{Fe}_{12.5}$ powder as a function of milling time (Al size of $44-88 \mathrm{\mu m}$, rotation speed $250 \mathrm{rpm}$, stearic acid as PCA).

SEM image presented in Fig. 2a shows the morphology of the cross-section of powder after $20 \mathrm{~h}$ of milling. The flattened particles of the initial powder which have been deformed by collision with the balls, as well as large agglomerates formed by welding mechanism could be seen. After $40 \mathrm{~h}$ of milling the homogeneous particles of completely mixed material were observed. The cracks visible inside the larger particles proved that the fragmentation process of the powder particles is not finished.

Increase of the milling speed up to $300 \mathrm{rpm}$ accelerates phase transformation changes during milling. After $8 \mathrm{~h}$ of milling the peaks of the $\mathrm{Al}, \mathrm{Cu}$ and $\mathrm{Fe}$ elements were not detected and the reflections in the positions corresponded to the quasicrystalline icosahedral i-phase
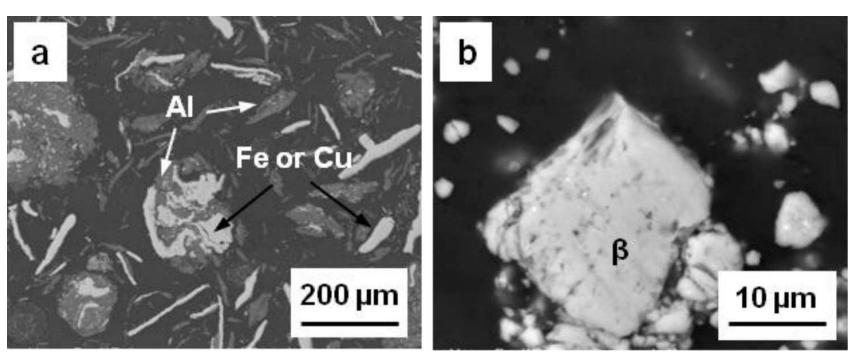

Fig. 2. SEM images of the cross-section of mechanically alloyed $\mathrm{Al}_{62} \mathrm{Cu}_{25.5} \mathrm{Fe}_{12.5}$ powder ( $\mathrm{Al}$ size of 44 $88 \mathrm{\mu m}$, rotation speed $250 \mathrm{rpm}$, stearic acid as PCA) after $20 \mathrm{~h}$ (a) and $40 \mathrm{~h}$ (b) of milling.

and the $\beta-\mathrm{Al}(\mathrm{Cu}, \mathrm{Fe})$ could be indexed (Fig. 3). Similar results for milled $\mathrm{AlCuFe}$ powder, where the quasicrystal was formed as a single phase or a mixture with the $\beta-\mathrm{Al}(\mathrm{Cu}, \mathrm{Fe})$ phase were reported in $[7,8,11-13]$. Upon continued milling up to $16 \mathrm{~h}$, the X-ray pattern showed the sharper reflections of the both phases, which indicates the crystalline size increase. No significant changes occurred during milling up to $32 \mathrm{~h}$ apart from a slight increase of intensity of $\beta-\mathrm{Al}(\mathrm{Cu}, \mathrm{Fe})$ phase reflections.

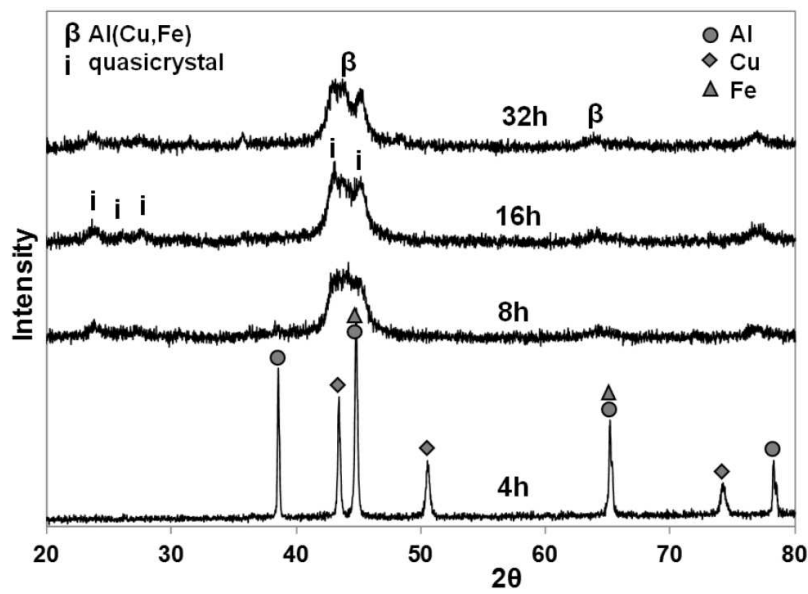

Fig. 3. X-ray diffraction patterns of mechanically alloyed $\mathrm{Al}_{62} \mathrm{Cu}_{25.5} \mathrm{Fe}_{12.5}$ powder as a function of milling time (Al size of $44-88 \mu \mathrm{m}$, rotation speed $300 \mathrm{rpm}$, stearic acid as PCA).

The solid state reaction between the elemental powders during milling is accelerated also by decrease of the initial $\mathrm{Al}$ powder size $(10 \mu \mathrm{m})$. In Fig. 4 a the set of X-ray diffraction patterns is presented for the milling with the rotational speed of $250 \mathrm{rpm}$ and the addition of stearic acid as PCA. After $10 \mathrm{~h}$ of milling the intensity of the reflection from pure $\mathrm{Al}, \mathrm{Cu}$ and $\mathrm{Fe}$ decreased and additional peak corresponding to the main reflection of the $\beta$ $\mathrm{Al}(\mathrm{Cu}, \mathrm{Fe})$ phase appears. Since the mechano-activated powder tends to ignite under the set experimental condition, the milling action was stopped at this stage and the next experiments were performed by using hexane as PCA. 
Figure $4 \mathrm{~b}$ shows the set of X-ray diffraction patterns for the milling speed $250 \mathrm{rpm}$ performed with hexane. After $10 \mathrm{~h}$ of milling the strong reflection at the position of $44^{\circ}$ indicates the presence of the $\beta-\mathrm{Al}(\mathrm{Cu}, \mathrm{Fe})$, although the weak reflections corresponding to $\mathrm{Al}$ are also visible. The absence of the reflections for $\mathrm{Cu}$ means that this element dissolved in the aluminum at first stage of milling. The prolonged milling time up to $20 \mathrm{~h}$ causes the disappearing of $\mathrm{Al}$ reflections and only reflections of the $\beta$ phase could be noticed. The broadening of the $\beta$ phase reflections increases after $40 \mathrm{~h}$ of milling which indicates the refinement of the crystalline size.

Wet milling in hexane eliminated tendency to ignite of milling powder. Hexane as a liquid media covered balls and milled powder and therefore was more effective for protection of the powder against oxidation and covering the ball and vials surface by milling powder than stearic acid.

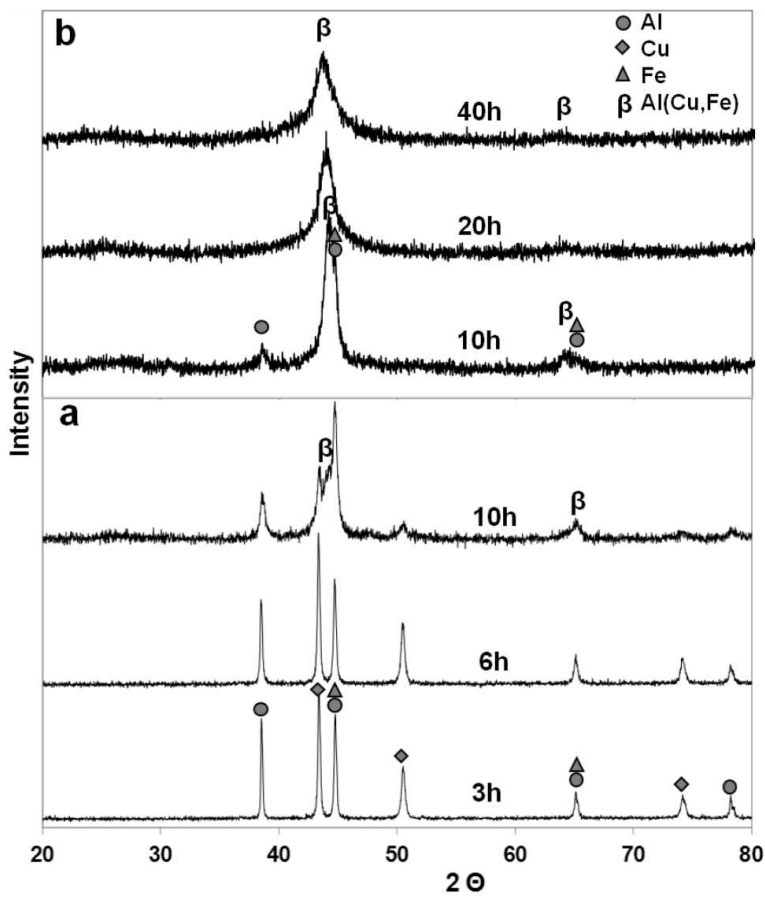

Fig. 4. X-ray diffraction patterns of mechanically alloyed $\mathrm{Al}_{62} \mathrm{Cu}_{25.5} \mathrm{Fe}_{12.5}$ powder as a function of milling time (Al size of $10 \mu \mathrm{m}$, rotation speed $250 \mathrm{rpm}$ ); (a) using stearic acid (longer milling results ignition of the powder) and (b) hexane as PCA (prevents the ignition of the powder).

The examples of the powder morphology evolution during milling with the speed $250 \mathrm{rpm}$ ( $\mathrm{Al}$ powder size of $10 \mu \mathrm{m}$ and the stearic acid media) are presented in Fig. 5. At the first stage of milling the flattened particles of starting elements tended to agglomerate (Fig. 5a) and then the near spherical particles of layered structure were formed (Fig. 5b). The refinement of the microstructure and reduce of powder particle size compared to that presented in Fig. 2 could be noticed. Based on XRD and
SEM experiments it could be concluded that decrease of the particles size of starting elemental powder enhances interdiffusion of $\mathrm{Fe}, \mathrm{Cu}$ and $\mathrm{Al}$ resulting in acceleration of the welding process during milling and also decrease of the final particle size of the powder.
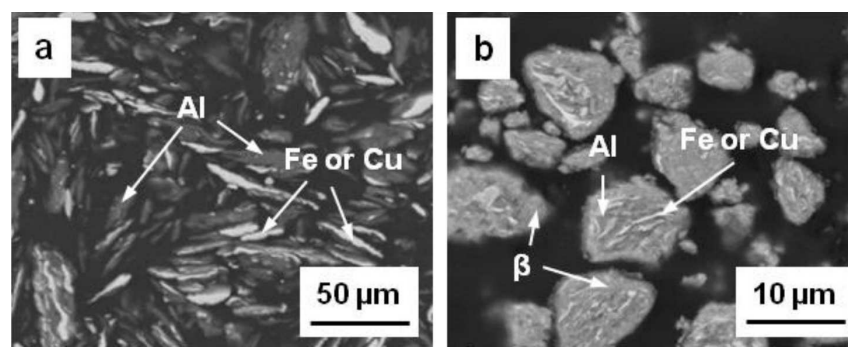

Fig. 5. SEM images of mechanically alloyed $\mathrm{Al}_{62} \mathrm{Cu}_{25.5} \mathrm{Fe}_{12.5}$ powder (Al size of $10 \mu \mathrm{m}$, rotation speed $250 \mathrm{rpm}$, stearic acid as PCA) after $6 \mathrm{~h} \mathrm{(a)}$ and $10 \mathrm{~h}(\mathrm{~b})$ of milling.

Increase of the milling speed up to $300 \mathrm{rpm}$ accelerates the formation of the $\beta-\mathrm{Al}(\mathrm{Cu}, \mathrm{Fe})$ phase, which could be seen as a main phase after $10 \mathrm{~h}$ of milling (Fig. 6). After $20 \mathrm{~h}$ of milling the additional reflection occurs near the strongest $\beta-\mathrm{Al}(\mathrm{Cu}, \mathrm{Fe})$ phase reflection, which could be identified as icosahedral i-phase. Prolonged milling time leads to transformation both the $\beta-\mathrm{Al}(\mathrm{Cu}, \mathrm{Fe})$ phase and i-phase to ordered $\beta$ phase with a $B 2$ structure (presence of a superlattice (100) reflection at $30.8^{c} \mathrm{irc}$ of $2 \Theta$ angle). Formation of ordered $\beta$ phase during high energy ball milling was shown by Wang et al. [9].

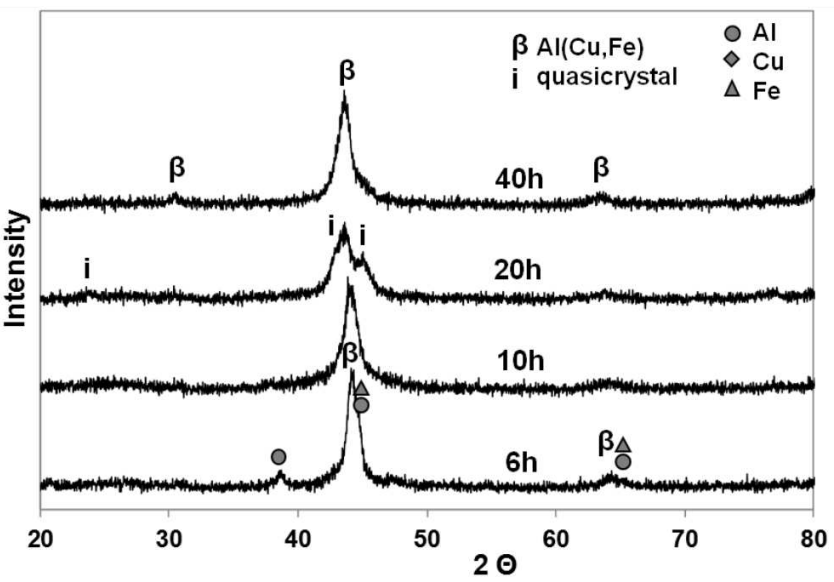

Fig. 6. X-ray diffraction patterns of mechanically alloyed $\mathrm{Al}_{62} \mathrm{Cu}_{25.5} \mathrm{Fe}_{12.5}$ powder as a function of milling time $(\mathrm{Al}$ size of $10 \mu \mathrm{m}$, rotation speed $300 \mathrm{rpm}$, hexane as PCA).

SEM images presented in Fig. 7 show the changes of the microstructure of the powder milled with rotation speed $300 \mathrm{rpm}$ by 6 and $20 \mathrm{~h}$. The mixed phases identified by XRD in the powder milled for $6 \mathrm{~h}$ are much more refined to compare to the powder milled with the speed 
$250 \mathrm{rpm}$ (Fig. 5). After $20 \mathrm{~h}$ of milling the microstructure is nearly homogeneous (the differences in the contrast between quasicrystal and $\beta$ phase are not visible because of their similar phase composition).
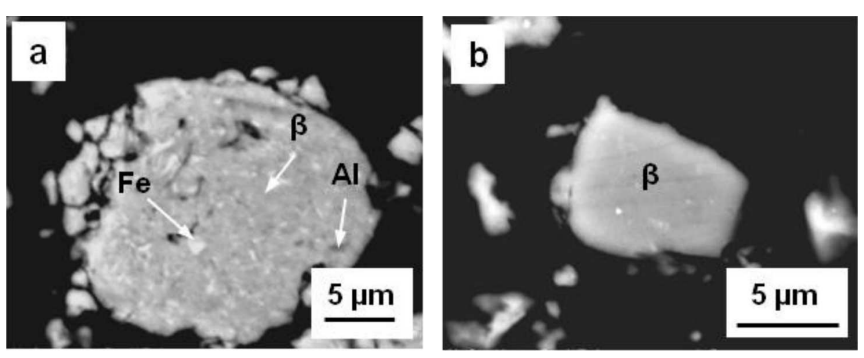

Fig. 7. SEM images of the cross-section of mechanically alloyed $\mathrm{Al}_{62} \mathrm{Cu}_{25.5} \mathrm{Fe}_{12.5}$ powder ( $\mathrm{Al}$ size of $10 \mu \mathrm{m}$, rotation speed $300 \mathrm{rpm}$, hexane as PCA) after $6 \mathrm{~h}$ (a) and $20 \mathrm{~h}(\mathrm{~b})$ of milling.

\section{Conclusions}

Increase of the rotation speed during ball milling as well as decrease of the particle size of the initial Al powder particles accelerate interdiffussion between elemental powder and lead to the formation of the homogeneous microstructure of $\mathrm{Al}_{62} \mathrm{Cu}_{25.5} \mathrm{Fe}_{12.5}$ powder.

Calculations of energy transferred between balls and milled powder show non-linear correlation between rotation speed and transferred energy. It can explain significant differences in phase composition in powders milled at 250 and $300 \mathrm{rpm}$.

Hexane as the process control agent eliminates tendency to ignite of powder during milling and is more effective for protection of the powder against oxidation than stearic acid.

The mixture of icosahedral quasicrystal and $\beta$ $\mathrm{Al}(\mathrm{Cu}, \mathrm{Fe})$ phase has been obtained for the powder milled at $300 \mathrm{rpm}$ by $20 \mathrm{~h}$. Prolonged milling time leads to the decrease of the quasicrystalline phase content and formation of the ordered $\beta$ phase with $B 2$ structure.

\section{Acknowledgments}

Financial support from the Polish National Science Centre NCN - research projects no 2011/03/B/ST8/05165 is gratefully acknowledged.

\section{References}

[1] Physical Properties of Quasicrystals, Ed. Z.M. Stadnik, Springer, Berlin 1999.

[2] E. Huttunen-Saarivirta, J. Alloys Comp. 363, 150 (2004).

[3] F. Faudot, A. Quivy, Y. Calvayrac, D. Gratias, M. Harmelin, Mater. Sci. Eng. A 133, 383 (1991).

[4] S.M. Lee, H.J. Jeon, B.H. Kim, W.T. Kim, D.H. Kim, Mater. Sci. Eng. A 304-306, 871 (2001).

[5] E. Huttunen-Saarivirta, J. Vuorinen, Intermetallics 13, 885 (2005).

[6] L. Lityńska-Dobrzyńska, J. Dutkiewicz, K. StanGłowińska, L. Dembinski, C. Coddet, P. Ochin, Acta Phys. Pol. A 126, 512 (2014).

[7] N. Asahi, T. Maki, S. Matsumoto, T. Sawai, Mater. Sci. Eng. A 181/182, 841 (1994).

[8] A.I. Salimon, A.M. Korsunsky, E.V. Shelekhov, T.A. Sviridova, S.A. Kaloshkin, V.S. Tcherdyntsev, Y.V. Baldokhin, Acta Mater. 49, 1821 (2001).

[9] B.B. Bokhonov, J. Alloys Comp. 461, 150 (2008).

[10] J. Eckert, L. Schultz, K. Urban, Acta Metall. Mater. 39, 1497 (1991).

[11] V. Srinivas, P. Barua, B.S. Murty, Mater. Sci. Eng. A 294-296, 65 (2000).

[12] P. Barua, B.S. Murty, B.K. Mathur, V. Srinivas, J. Appl. Phys. 91, 5353 (2002).

[13] B.S. Murty, R.V. Koteswara Rao, N.K. Mukhopadhyay, J. Non-Cryst. Solids 334-335, 48 (2004).

[14] Y. Wang, Y. Tian, Y. Wang, H. Geng, Z. Zhang, Intermetallics 16, 121 (2008).

[15] X. Yong, I.T. Chang, I.P. Jones, J. Alloys Comp. 387, 128 (2005).

[16] V. V. Tcherdyntsev, S.D. Kaloshkin, E.V. Shelekhov, A.I. Salimon, S. Sartori, G. Principi, Intermetallics 13, 841 (2005).

[17] F. Turquier, V.D. Cojocaru, M. Stir, R. Nicula, E. Burkel, J. Non-Cryst. Solids 353, 3417 (2007).

[18] R. Nicula, K. Ishizaki, M. Stir, Z. Shen, S. Vaucher, Philos. Mag. 91, 2450 (2011).

[19] M. Gogebakan, B. Avar, Pramana-J. Phys. 77, 735 (2011).

[20] D.N. Travessa, K.R. Cardoso, W. Wolf, A.M. Jorge Jr, W.J. Botta, Mater. Res. 5, 749 (2012).

[21] N. Burgio, A. Iasonna, M. Magini, S. Martelli, F. Padella, Nuovo Cim. 13, 459 (1991).

[22] M. Abdealloui, E. Gaffet, Acta Metall. Mater. 43 , 1087 (1995). 